\title{
Aplikasi Sistem Informasi Koperasi Simpan Pinjam Berbasis Web Pada PT. Mitraindo Sejahtera Utama Tangerang
}

\author{
Ari Abdilah ${ }^{1}$, Elah Nurlelah ${ }^{2}$, Fuad Nur Hasan ${ }^{3}$, Dwi Yuni Utami ${ }^{4}$ \\ ${ }^{1}$ Universitas Bina Sarana Informatika, Teknologi Informasi \\ 1ari.aab@bsi.ac.id \\ ${ }^{2}$ Universitas Bina Sarana Informatika, Sistem Informasi \\ 2elah.enl@bsi.ac.id \\ ${ }^{3}$ Universitas Bina Sarana Informatika, Ilmu Komputer \\ ${ }^{3}$ fuad.fnu@bsi.ac.id \\ ${ }^{4}$ Universitas Bina Sarana Informatika, Teknologi Komputer \\ ${ }^{4}$ dwi.dyu@bsi.ac.id

\begin{tabular}{ccc}
\hline Diterima & Direvisi & Disetujui \\
$24-10-2021$ & $30-12-2021$ & $12-01-2022$ \\
\hline
\end{tabular}

\begin{abstract}
Abstrak - Koperasi karyawan PT. Mitraindo Sejahtera Utama cara kerjanya masih menggunakan sistem secara manual menggunakan Microsoft Excel, sehingga informasi yang dihasilkan kurang akurat dan kemungkinan terjadi kesalahan dalam proses pendataan dan perhitungan. Penelitian ini memiliki tujuan untuk membuat sebuah aplikasi tentang simpan pinjam berbasis web pada koperasi karyawan PT. Mitraindo Sejahtera Utama. Dengan dibuatnya aplikasi berbasis web ini peneliti berharap dapat mengurangi beberapa kesalahan Dengan adanya aplikasi ini diharapkan dapat mengurangi beberapa kesalahan yang sering terjadi dalam pengolahan data dan proses simpan pinjam pada Koperasi karyawan PT. Mitraindo Sejahtera Utama dapat berjalan dengan lancar, dan proses kerja kayawanpun menjadi lebih cepat dan akurat. Peneliti menggunakan metode rancangan software yaitu dengan cara menganalisa sistem yang sedang berjalan pada koperasi karyawan PT. Mitraindo Sejahtera Utama meliputi desain sistem, desain database dan implementasi sistem. Laporan yang dihasilkan meliputi laporan untuk data anggota, data simpanan anggota, laporan data pinjaman serta laporan tentang angsuran pinjaman. Bahasa pemograman yang digunakan adalah PHP My SQL, software yang penulis gunakan untuk mendukung dalam proses pembuatan aplikasi yaitu Dreamweaver CS6, Adobe photoshop dan Xampp.
\end{abstract}

Kata Kunci: Sistem Informasi, Web, Simpan Pinjam, PT. Mitraindo Sejahtera Utama Tangerang

\begin{abstract}
Cooperative employees of PT. Mitraindo Sejahtera Utama, the way it works is still using the system manually using Microsoft Excel, so the information produced is less accurate and there may be errors in the data collection and calculation process. This study aims to create an application about web-based savings and loans at the employee cooperative of PT. Mitraindo Sejahtera Utama. By making this web-based application, researchers hope to reduce some errors. With this application, it is expected to reduce some errors that often occur in data processing and the savings and loan process at the Cooperative employees of PT. Mitraindo Sejahtera Utama can run smoothly, and the employee's work process becomes faster and more accurate. Researchers use the software design method, namely by analyzing the system that is running at the employee cooperative of PT. Mitraindo Sejahtera Utama covers system design, database design and system implementation. The reports generated include reports for member data, member savings data, loan data reports and reports on loan installments. The programming language used is PHP My SQL, the software that the author uses to support the process of making applications, namely Dreamweaver CS6, Adobe Photoshop and Xampp.
\end{abstract}

Keywords: Information Systems, Web, Savings and Loans, PT. Mitraindo Sejahtera Utama Tangerang

\section{PENDAHULUAN}

Bagian tak terpisahkan dari pembangunan nasional yaitu koperasi. UUD (Undang-Undang Dasar) menempatkan koperasi ini sebagai soko guru perekonomian pada Indonesia, maka atas dasar tersebut, koperasi sebagai organisasi ekonomi dan sosial berusaha untuk meningkatkan kesejahteraan masyarakat pada umumnya dan kesejahteraan para para anggotanya (Suryaningsih \& Kartika, 2019). 
Koperasi simpan pinjam adalah sebagai satu-satunya usaha yang dilakukan secara syariah (konvensional) yang merupakan usaha untuk menjalankan usaha simpan pinjam yang menyediakan pinjam uang kepada peminjam dalam hal ini yaitu anggota sesuai dengan perjanjian, dan anggota atau peminjam diwajibkan untuk membayar jasa dan diwajibkan untuk melunasi pinjaman tersebut dengan tepat waktu sesuai dengan waktu yang telah ditentukan (Raharjo et al., 2021).

Koperasi karyawan PT. Mitraindo Sejahtera Utama (KOPKARMISU) merupakan sebuah lembaga keuangan ekonomi yang berada dilingkugan perusahaan PT. Mitraindo Sejahtera Utama. Dalam Koperasi pada perusahaan ini memiliki jumlah anggota cukup banyak dan tentunya dengan berbagai macam produk yang telah disediakan untuk para anggota koperasi, salah satu yang disediakan oleh perusahaan yaitu layanan simpan pinjam. Pada layanan ini lebih banyak diminati oleh para anggota koperasi dan layanan ini merupakan layanan yang bersifat jasa. Layanan koperasi simpan pinjam apabila jumlah anggota koperasinya banyak tentunya secara otomatis akan menyebabkan menjadi besarnya layanan ini, oleh sebab itu berdasarkan penjelasan tersebut, dalam perusahaan ini ternyata masih menggunakan sistem yang masih manual (belum terkomputerisasi) atau belum memiliki informasi sendiri terutama dalam hal komunikasi data dan banyaknya yang menangani sistem tersebut dari mulai admin, bendahara dan sekretaris karena belum adanya sistem khusus untuk mengelola simpan pinjam yang memudahkan proses pengelolaan data, mengolah data dan proses menyampaikan kepada anggota terkait informasi tersebut.

Data transaksi pengembalian dan biaya-biaya administrasi, nominatif pinjaman dan nominatif tabungan, laporan, serta buku kas masih dilakukan menggunakan Microsoft Excel. Dengan begitu hal inilah yang tentunya menyebabkan repotnya proses pengerjaan dan menyebabkan adanya beberapa proses yang terjadi diluar ekspetasi dan tidak sesuai dengan prosedur yang ada. Oleh karena itu, kinerja pada koperasi KOPKARMISU perlu penerapan teknik manajemen untuk mengelola berbagai informasi yang ada agar informasi yang dikelola dapat menjadi sesuatu yang sangat bermanfaat dalam membantu proses pengelolaan kepengurusan koperasi terutama untuk pelayanan kepada setiap anggotanya. Anggraeni et al mengemukakan bahwa "Proses simpan pinjam di KUD Mandiri Bayongbong didapatkan keterangan bahwa sistem yang sedang berjalan di KUD Mandiri Bayongbong masih dilakukan secara manual, sehingga akan berpengaruh pada efesiensi waktu dan tenaga. Keamanan dan pengolahan datapun diragukan kebenaranya karena tidak menutup kemungkinan adanya kecurangan yang disengaja maupun tidak disengaja" (Fridayanthie \& Charter, 2016).
Berdasarkan kebutuhan diatas, maka perlu adanya sebuah sistem dengan berbasiskan web yang dapat mengelola data-data pada simpan pinjam koperasi sehingga informasi yang disampaikan kepada anggota tentang simpan pinjam dapat sesuai dengan apa yang dibutuhkan. Dengan dibangunnya sistem informasi koperasi simpan pinjam dan dengan digunakannya penyimpanan database, dapat memudahkan pengurus koperasi serta anggota dalam mengolah data transaksi, memudahkan proses pembuatan laporan karena data sudah tersimpan dalam satu pusat database atau basis data dan kontrol transparansi pun lebih mudah (Syahrul \& Desmulyati, 2019).

\section{METODOLOGI PENELITIAN}

Dalam penelitian ini, metode penelitian yang digunakan penulis adalah:

\section{Metode Pengembangan Perangkat Lunak}

Metode penelitian dan teknik pada pengembangan sistem ini menggunakan metode SDLC (Software Development Life Cycle), dengan model waterfall. Menurut (Rosa A.S \& M. Shalahudin, 2018) "Model SDLC air terjun (waterfall) sering juga disebut sekuensial linier (sequential linear) atau alur hidup klasik (classic life cycle)".

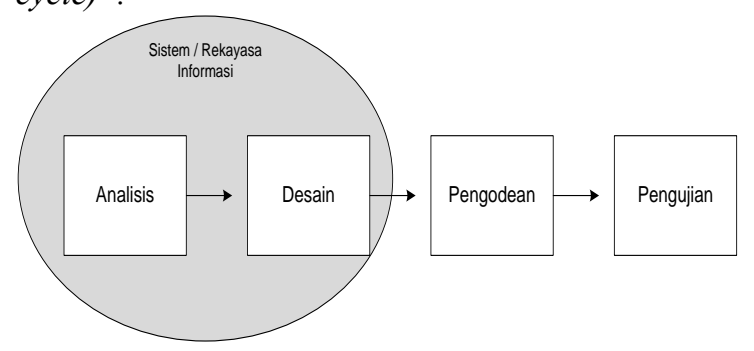

Gambar 1. Model Waterfall

Sumber: (Rosa A.S \& M. Shalahudin, 2018)

a. Analisa Kebutuhan Sistem

Analisa kebutuhan sistem merupakan tahap dimana peneliti harus lebih teliti dalam tahap ini dikarenakan apabila ada kesalahan akan menyebabkan beberapa kesalahan juga ditahap berikutnya. Dengan mengamati langsung transaksi-transaksi yang dilakukan seperti proses peminjaman masih bersifat manual. Maka interface yang diperlukan yaitu: form simpanan, form pinjaman, form anggota, form angsuran serta form laporan penyimpanan dan peminjaman.

b. Desain

Dalam tahap ini peneliti membuat beberapa perencanaan yang tentunya berhubungan dengan pembahasan sistem yang akan dibuat. Desain sistem informasi yang diusulkan yaitu: UML (Unified Modeling Languange), dengan menggunakan Use Case Diagram, Activity Diagram, Component Diagram dan Deployment Diagram. Untuk rancangan database dengan 
menggunakan ERD (Entity Relationship Diagram).

c. Code Generation

Setelah sesuai dengan tahap-tahap diatas penulis menggunakan perangkat lunak seperti PHP MyAdmin dan Mysql ataupun perangkat lunak lainya untuk membuat suatu sistem informasi berbasis web. Pemograman yang digunakan adalah pemograman terstruktur.

d. Testing

Pengujian ini dimaksudkan untuk melihat seberapa baik sistem yang telah dibangun, dan pengujian ini, metode yang dipakai adalah blackbox testing yang berarti bahwa pengujian suatu aplikasi harus terdapat pada inputan dan ouput atau keluaran atas penilaian suatu aplikasi dan tidak terdapat pada fungsi dari aplikasi atau spesifikasi logikanya saja. Tentunya suatu sistem aplikasi akan menghasilkan output yang sesuai dengan harapan dari penguji karena adanya berbagai macam inputan atau masukan dan sudah dievaluasi dengan sangat maksimal.

e. Support

Dalam penulisan ini peneliti didukung hardware dengan Microsoft Windows 7 untuk sistem operasi, database, PHPMyAdmin dan MySql, serta dibantu menggunakan RAM 2 GB dan VGA 1 GB.

\section{Teknik Pengumpulan Data}

Teknik pengumpulan data yang digunakan meliputi:

a. Observasi

Observasi merupakan pengamatan secara langsung atau tidak langsung terhadap suatu objek yang diteliti dengan tujuan untuk memperoleh data yang harus dikumpulkan dalam penelitian. Observasi terhadap objek dapat dilakukan langsung di tempat berlangsungnya peristiwa atau kejadian sehingga observasi berada bersama objek yang sedang diamati yang disebut dengan observasi secara langsung (Haerudin et al., 2020).

Pada tahap ini peneliti melakukan penelitian dan pengamatan secara langsung terhadap obyek yang diselidiki yaitu mengenai proses simpan pinjam pada koperasi karyawan PT. Mitraindo Sejahtera Utama

b. Wawancara

Wawancara adalah teknik pengumpulan data untuk mencari informasi yang dibutuhkan dalam penelitian dan dilakukan secara langsung kepada sumbernya (Saktisyahputra, 2019).

Pada tahap ini peneliti melakukan proses tanya jawab secara langsung kepada ketua koperasi serta pengurus koperasi karyawan PT. Mitraindo Sejahtera Utama. Peneliti melakukan proses tanya jawab tentang permasalahan yang dihadapi dan tentunya yang berkaitan dengan yang sedang diamati oleh peneliti.

c. Studi Pustaka

Studi pustaka merupakan metode pengumpulan yang dilakukan dengan cara mengumpulkan data-data sekunder yang diambil dari beberapa sumber seperti buku, jurnal dan literatur serta referensi yang berkaitan dengan penelitian dan sudah dirancang secara terstruktur(Sondak et al., 2019).

Peneliti juga melakukan studi pustaka untuk melengkapi data-data yang terdapat dalam jurnal, e-book dan dengan mendalami catatan kuliah yang berkaitan dengan permasalahan yang dibahas. Pada penelitian ini peneliti melakukan studi selama priode penelitian. Studi pustaka ini penting sebagai dasar teoritis untuk melakukan penelitian-penelitian selanjutnya.

\section{HASIL DAN PEMBAHASAN}

A. Proses Bisnis Berjalan

Koperasi Karyawan PT. Mitraindo Sejahtera Utama (KOPKARMISU) adalah sebuah organisasi yang berada didalam lingkungan perusahaan yang hanya beranggotakan karyawan yang masih aktif bekerja di PT. Mitraindo Sejahtera Utama. Proses Bisnis yang dilakukan di PT. Mitraindo Sejahtera Utama masih bersifat manual. Dalam proses pengajuan simpan pinjam koperasi ini, diawali ketika anggota koperasi mengisi form simpan pijam kemudian menyerahkan kepada petugas koperasi. Pada proses simpanan petugas koperasi akan meneruskan informasi ke bagian keuangan. Selanjutnya Pada proses peminjaman petugas koperasi akan mengecek kelengkapan syarat-syarat, apabila tidak memenuhi syarat maka pengajuan pinjaman ditolak. Kemudian apabila memenuhi syarat maka petugas koperasi akan menandatangani permohonan pinjaman dan meneruskan informasi kepada ketua koperasi. Ketua koperasi akan menandatangani form permohonan pengajuan pinjaman, setelah itu ketua koperasi menyerahkan balik form permohonan pinjaman ke petugas koperasi. 


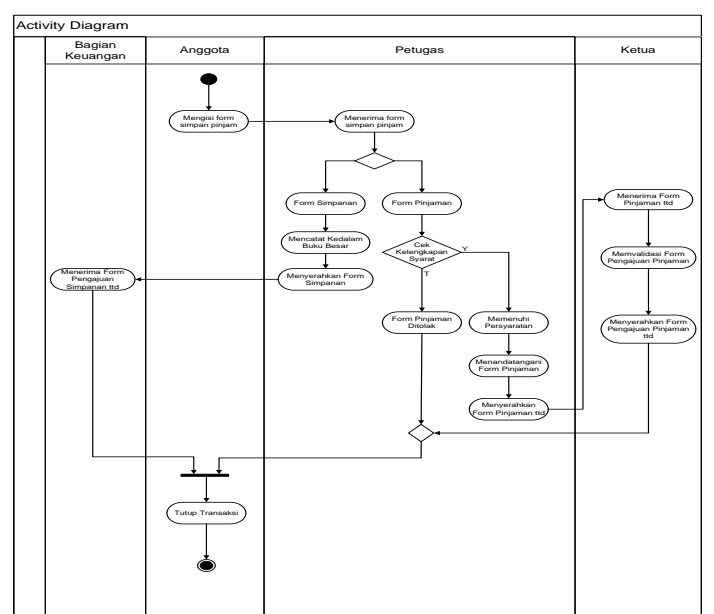

Gambar 2. Activity Diagram Sistem Berjalan

Sumber : (Abdilah et al., 2021)

B. Rancangan Diagram Usecase

Rosa dan Shalahudin mengemukakan bahwa Diagram use case adalah menggambarkan model yang akan dibuat dari sebuah sistem informasi untuk behavior. Dalam diagram use case terdapat aktor yang dapat dideskripsikan dengan cara berinteraksi antara satu atau lebih aktor tersebut (Fridayanthie \& Mahdiati, 2016).

Berikut merupakan usecase diagram halaman admin yang penulis buat. Dalam sistem ini admin yang menjadi actor, yang dapat menjalankan sistem sesuai denga hak akses yang diberikan.

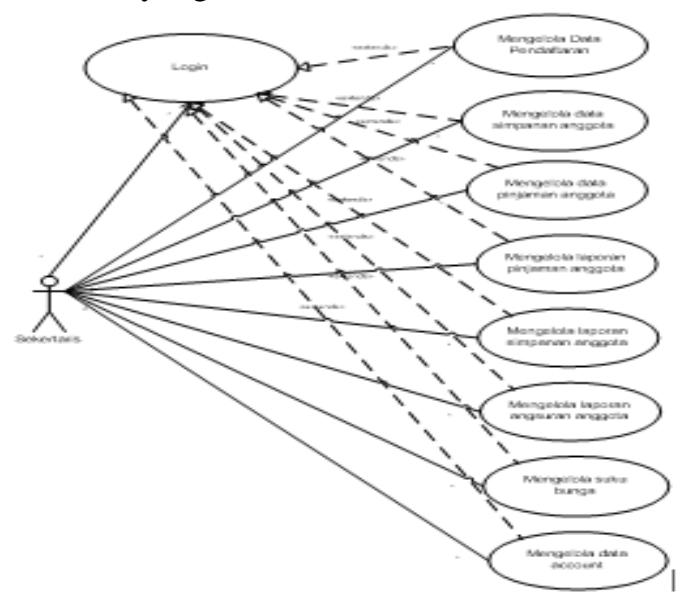

Gambar 3. Use Case Diagram Halaman Admin Sumber : (Abdilah et al., 2021)

\section{Diagram Aktivitas (Activity Diagram)}

Rosa dan Shalahudin mengemukakan bahwa "Activity diagram menggambarkan aktivitas atau aliran kerja (workflow) dari sebuah proses bisnis sistem atau menu yang ada pada software (perangkat lunak). (Fridayanthie \& Mahdiati, 2016).

Berikut merupakan activity diagram dari sistem Informasi Koperasi Simpan Pinjam.

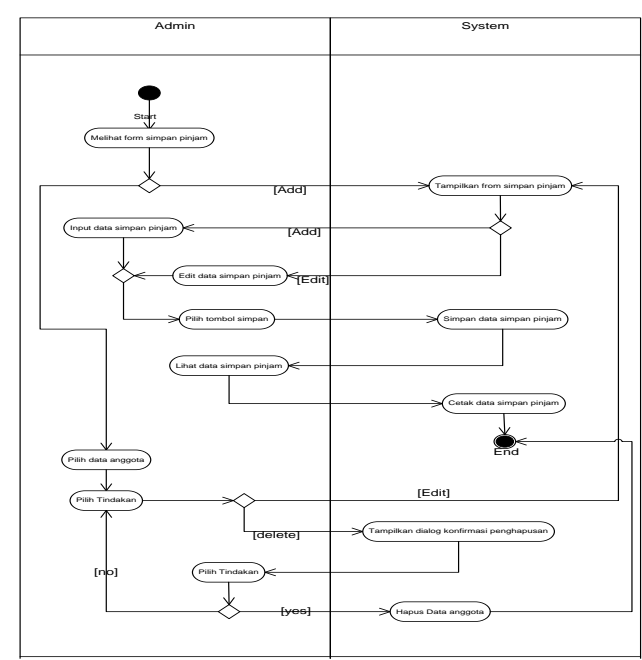

Gambar 4. Activity Diagram Halaman Admin Sumber : (Abdilah et al., 2021)

D. Rancangan Database

1. Entity Relationship Diagram

Entity Relationship Diagram (ERD) merupakan tool analisis sistem pertama yang memusatkan pada data dan keterkaitan antar data serta pengorganisasian data. ERD juga menggambarkan hubungan antara satu entitas yang memiliki sejumlah atribut dengan entitas yang lain dalam suatu sistem yang terintegrasi (Palasara et al., 2019).

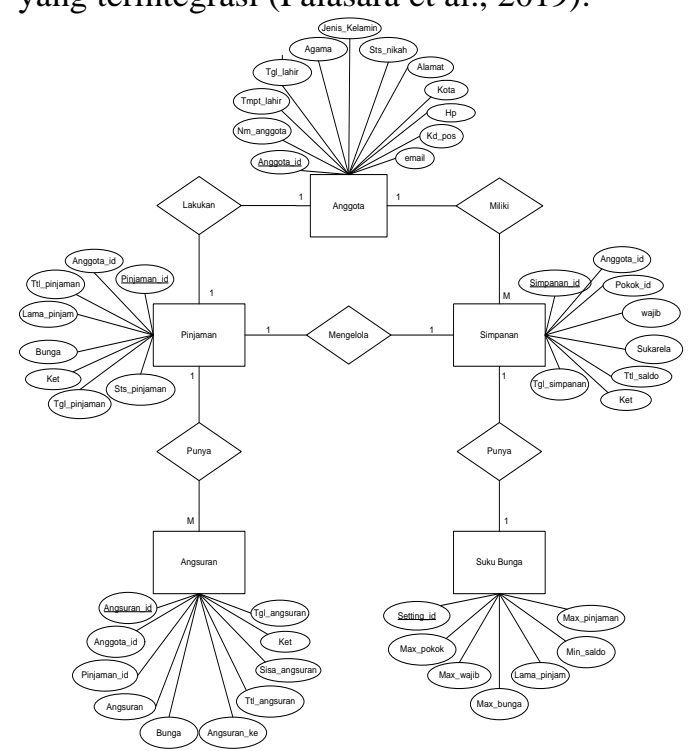

Gambar 5. Entity Relationship Diagram

Sumber : (Abdilah et al., 2021)

\section{Logical Record Structure}

Syabaniah et al mengemukakan bahwa "LRS merupakan model sistem yang digambarkan berupa tabel yang terbentuk dari hasil relasi antar himpunan entitas-entitas yang mengikuti pola tertentu" (Ardiyansyah \& Iramayani, 2021). 


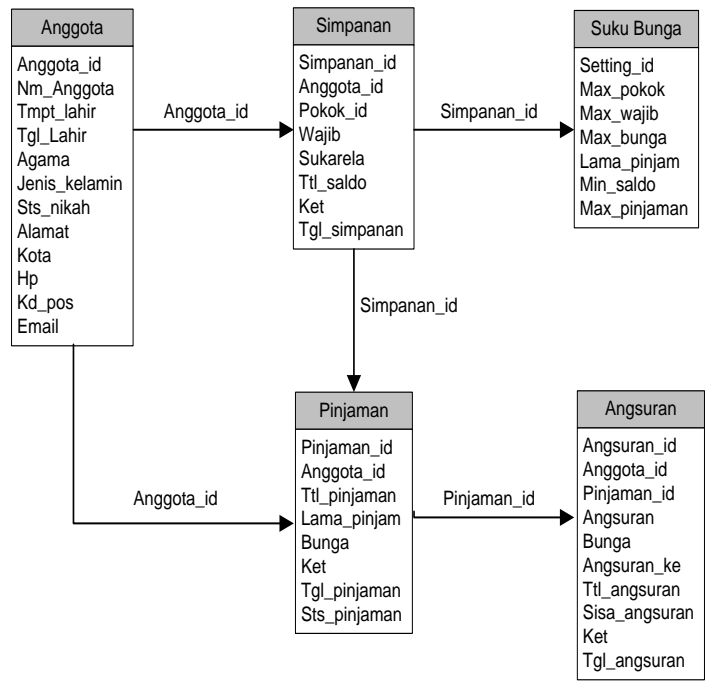

Gambar 6. Logical Record Structure

Sumber : (Abdilah et al., 2021)

\section{E. Rancangan Database \\ 1. Component Diagram}

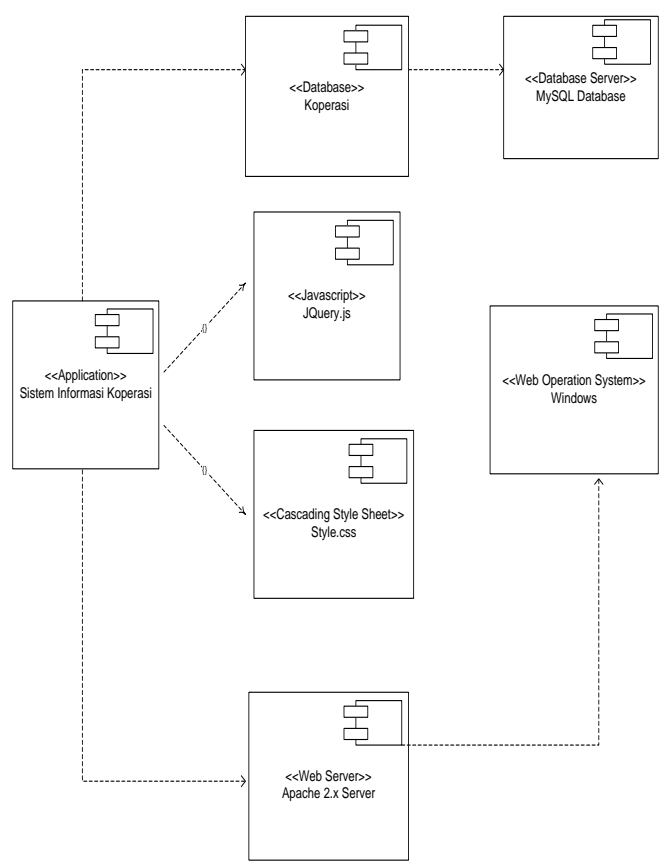

Gambar 7. Component Diagram

Sumber : (Abdilah et al., 2021)

\section{Deployment Diagram}

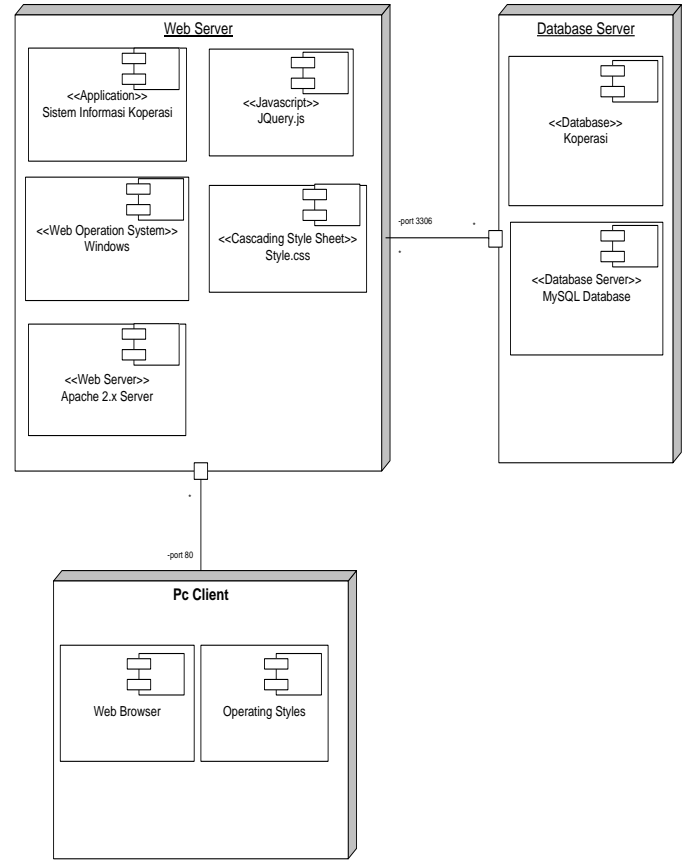

Gambar 8. Deployment Diagram Sumber : (Abdilah et al., 2021)

\section{F. User Interface}

Berikut adalah desain tampilan user interface dari sistem informasi koperasi simpan pinjam PT. Mitraindo Sejahtera Utama:

\section{Halaman Login}

Halaman ini yaitu halaman untuk login. Sebelum ke halaman ini diharuskan untuk melakukan pengisian username dan password yang benar. Halaman ini merupakan halaman security sebelum memasuki ke halaman utama.

\section{Login Koperasi}

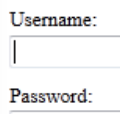

Password:

\section{Login}

Gambar 9. Halaman Login

Sumber : (Abdilah et al., 2021)

\section{Halaman Utama}

Halaman utama merupakan halaman untuk mengelola data pengguna, data anggota, data simpanan dan pinjaman anggota serta laporan simpanan, pinjaman serta angsuran pinjaman anggota. 


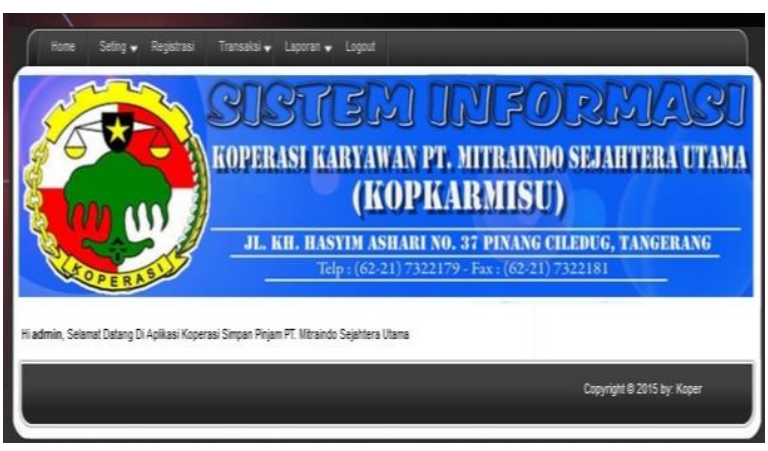

Gambar 10. Halaman Utama

Sumber : (Abdilah et al., 2021)

\section{Halaman Pengguna}

Halaman pengguna merupakan halaman admin yang dimana admin dapat menambah, mengedit, mengapus, dan melihat data pengguna baru.

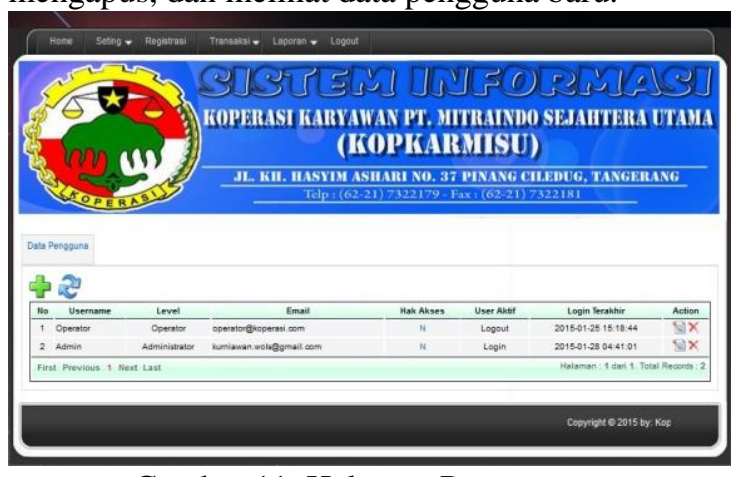

Gambar 11. Halaman Pengguna

Sumber : (Abdilah et al., 2021)

\section{Halaman Anggota}

Halaman anggota merupakan halaman admin, yang dimana admin dapat menambah, mengapus, mengedit, mencetak dan melihat daftar anggota.

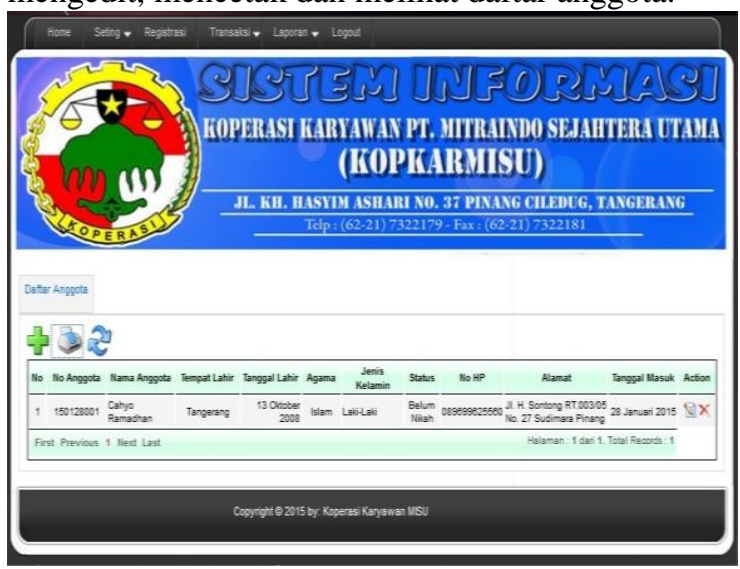

Gambar 12. Halaman Anggota

Sumber : (Abdilah et al., 2021)

\section{Halaman Simpanan Anggota}

Halaman simpan anggota merupakan halaman admin yang dimana admin dapat menambah, mengapus, mencetak dan melihat daftar simpanan anggota.

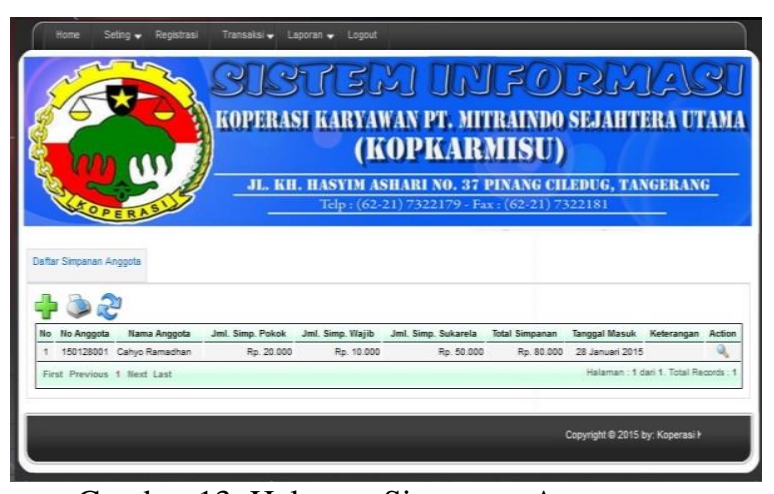

Gambar 13. Halaman Simpanan Anggota

Sumber : (Abdilah et al., 2021)

6. Halaman Pinjaman Anggota

Halaman pinjaman anggota merupakan halaman admin yang dimana admin dapat menambahkan berapa besar pinjaman setiap anggota.

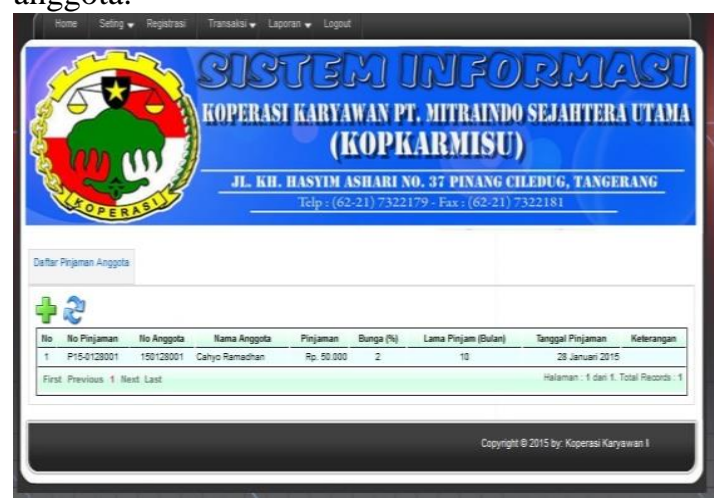

Gambar 14. Halaman Pinjaman Anggota

Sumber : (Abdilah et al., 2021)

\section{Halaman Laporan Pinjaman}

Halaman laporan pinjaman merupakan halaman admin, yang dimana admin dapat mencari, mencetak laporan pinjaman setiap anggota.

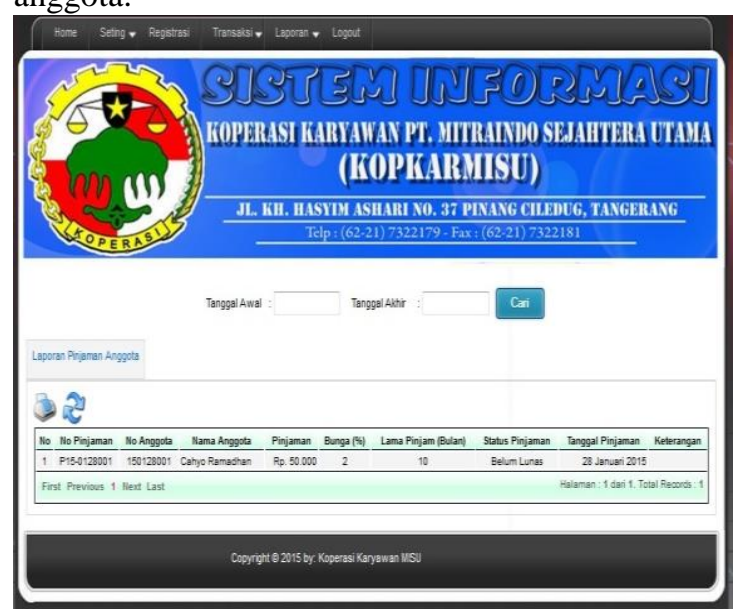

Gambar 15. Halaman Laporan Pinjaman Sumber : (Abdilah et al., 2021)

\section{Halaman Laporan Angsuran Pinjaman Anggota}




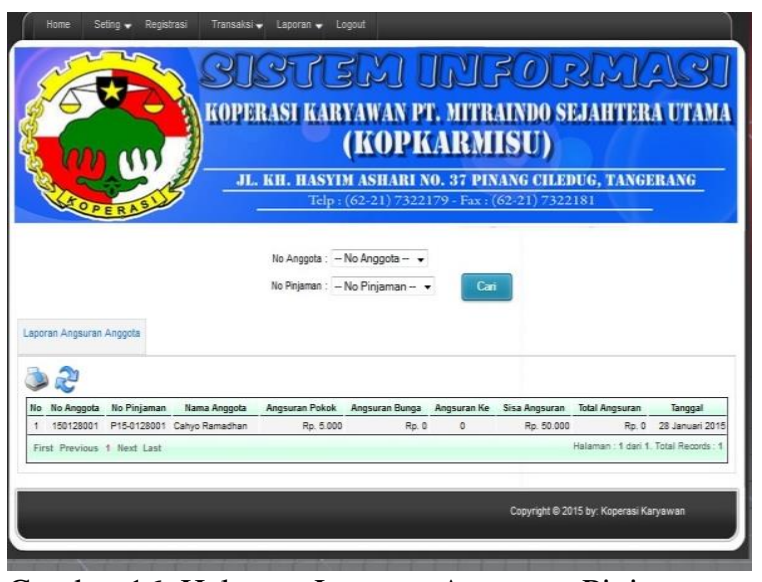

Gambar 16. Halaman Laporan Angsuran Pinjaman Anggota

Sumber : (Abdilah et al., 2021)

\section{G. Testing}

Peneliti menggunakan pengujian blackbox testing, testing dilakukan dengan menguji sistem informasi simpan pinjam koperasi, seperti pengujian terhadap Form Pinjaman Anggota.

Tabel 1. Hasil Pengujian Black Box Testing Pinjaman Anggota

\begin{tabular}{|c|c|c|c|c|c|}
\hline $\begin{array}{l}\mathrm{N} \\
\text { o. }\end{array}$ & $\begin{array}{c}\text { Skena } \\
\text { rio } \\
\text { pengu } \\
\text { jian }\end{array}$ & $\begin{array}{l}\text { Test } \\
\text { case }\end{array}$ & $\begin{array}{c}\text { Hasil } \\
\text { yang } \\
\text { diharap } \\
\text { kan }\end{array}$ & $\begin{array}{c}\text { Hasil } \\
\text { pengujia } \\
n\end{array}$ & $\begin{array}{c}\text { Kesimp } \\
\text { ulan }\end{array}$ \\
\hline 1. & $\begin{array}{l}\text { Admi } \\
\mathrm{n} \\
\text { meng } \\
\text { input } \\
\text { kan } \\
\text { data } \\
\text { pinja } \\
\text { man } \\
\text { denga } \\
\text { n } \\
\text { meng } \\
\text { klik } \\
\text { ikon } \\
\text { "Tam } \\
\text { bah } \\
\text { Data” }\end{array}$ & $\begin{array}{l}\text { Klik } \\
\text { "Tam } \\
\text { bah } \\
\text { Data" }\end{array}$ & $\begin{array}{l}\text { Sistem } \\
\text { akan } \\
\text { menam } \\
\text { pilkan } \\
\text { form isi } \\
\text { pinaja } \\
\text { man } \\
\text { anggota }\end{array}$ & $\begin{array}{l}\text { Sesuai } \\
\text { harapan }\end{array}$ & Valid \\
\hline
\end{tabular}

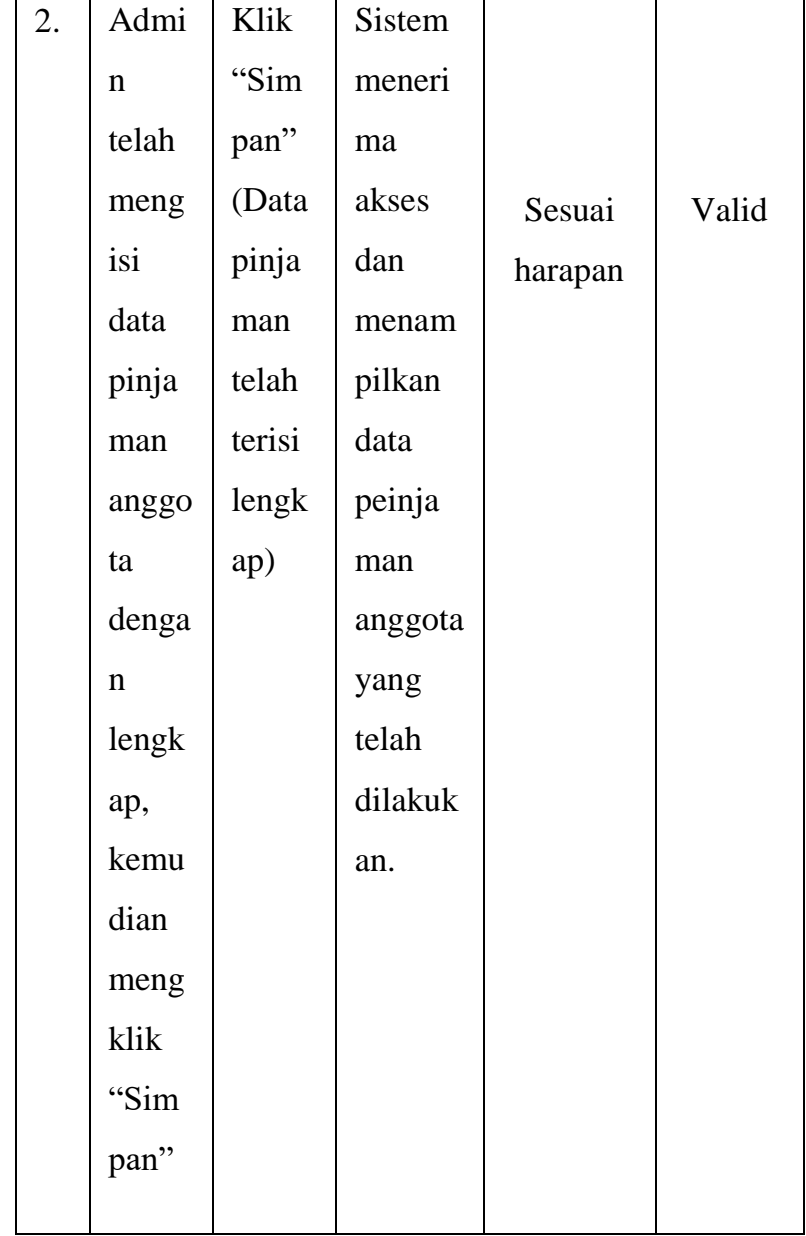

Sumber : (Abdilah et al., 2021)

\section{KESIMPULAN}

Berdasarkan penelitian yang telah dilakukan pada PT. Mitraindo Sejahtera Utama khususnya pada sistem informasi simpan pinjam koperasi, ada beberapa kesimpulan yang dapat peneliti tarik diantaranya:

1. Pembuatan laporan simpan pinjam secara manual dapat membutuhkan waktu yang lama sehingga banyak mengandung resiko kesalahan.

2. Dengan menggunakan sistem secara manual, proses penyajian keluaran atau informasi menjadi kurang tepat dan kurang relevan.

3. Proses pengerjaanpun menjadi lebih lama karena proses pencarian dan perubahan datanya membutuhkan waktu yang lama.

Oleh karena itu, untuk mengatasi permasalahan tersebut perlu dibuat sebuah sistem informasi, tentunya sebuah sistem informasi tentang simpan pinjam berbasiskan web, dengan berbasiskan web informasi yang berkualitaspun dapat mudah didapatkan serta memudahkan dalam proses pengambilan keputusan, dan tentunya memiliki banyak keuntungan, antara lain: 
1. Adanya sistem informasi simpan pinjam berbasiskan web mampu menghasilkan keluaran atau informasi yang lebih tepat.

2. Dapat menghemat waktu dalam pemasukan, pencarian dan perubahan data.

3. Tidak memerlukan banyak tenaga dalam pengerjaanya.

4. Website dirancang dan dibuat dengan sangat menarik sehingga dapat mempermudah dalam proses pemakaian.

5. Dengan adanya sistem informasi simpan pinjam secara terkomputerisasi tentunya mampu meningkatkan kinerja SDM dalam rangka pembuatan informasi akuntansi.

\section{REFERENSI}

Abdilah, A., Nurlelah, E., \& Hasan, F. N. (2021). Aplikasi Sistem Informasi Koperasi Simpan Pinjam Berbasis Web Pada PT. Mitraindo Sejahtera Utama Tangerang.

Ardiyansyah, \& Iramayani. (2021). RANCANG BANGUN SISTEM INFORMASI AKUNTANSI PENDAPATAN JASA PADA RUMAH SUSUN SEDERHANA SEWA (RUSUNAWA) HARAPAN JAYA PONTIANAK. 5(1), 9-18.

Fridayanthie, E. W., \& Charter, J. (2016). Rancang Bangun Sistem Informasi Simpan Pinjam Karyawan Menggunakan Metode Object Oriented Programming (Studi Kasus: PT. Arya Buana Sakti Tangerang). Jurnal Techno Nusa Mandiri, 13(2), 149-156. http://ejournal.nusamandiri.ac.id/index.php/tec hno/article/view/207/183

Fridayanthie, E. W., \& Mahdiati, T. (2016). Rancang Bangun Sistem Informasi Permintaan Atk Berbasis Intranet (Studi Kasus: Kejaksaan Negeri Rangkasbitung). Jurnal Khatulistiwa Informatika, 4(3), 126-138.

Haerudin, Yulistina Nur DS, \& Urwatil Wusko. (2020). Analysis of Students' Environmental Care Attitudes at SDIT AL-IRSYADIYYAH. Jurnal Sekolah Dasar, 5(2), 92-97. https://doi.org/10.36805/jurnalsekolahdasar.v5 i2. 1147

Palasara, N., Ahmad Sinnun, \& Muhamad Tabrani.
(2019). Penerapan Metode Waterfall Pada Sistem Informasi Manajemen Buku Perpustakaan Berbasis Web. Jurnal SAINTEKOM, 9(1), 83. https://doi.org/10.33020/saintekom.v9i1.84

Raharjo, J. S. D., Sidik, A., \& Marbun, N. (2021). Aplikasi Koperasi Simpan Pinjam Berbasis Web (Studi Kasus Torus Jaya Mandiri). Academic Journal of Computer Science Research, 3(1), 1-4. https://doi.org/10.38101/ajcsr.v3i1.329

Rosa A.S, \& M. Shalahudin. (2018). Rekayasa Perangkat Lunak Terstruktur dan Berorientasi Objek. Informatika.

Saktisyahputra, S. (2019). Pemanfaatan Website WWW.Pulokambing.Com Sebagai Media Rumah Kreatif Bersatu Nusantara (RKBN) Pulokambing Dalam Pemberdayaan Masyarakat. Jurnal Komunitas : Jurnal Pengabdian Kepada Masyarakat, 1(2), 9-15. https://doi.org/10.31334/jks.v2i1.287

Sondak, S. H., Taroreh, R. N., \& Uhing, Y. (2019). Faktor-Faktor Loyalitas Pegawai Di Dinas Pendidikan Daerah Provinsi Sulawesi Utara. Jurnal EMBA: Jurnal Riset Ekonomi, Manajemen, Bisnis Dan Akuntansi, 7(1), 671680. https://doi.org/10.35794/emba.v7i1.22478

Suryaningsih, K. A., \& Kartika, I. N. (2019). Pengaruh Variasi Produk, Pembinaan Usaha,Dan Persaingan Usaha, Terhadap Keberlangsungan Usaha Koperasi. E-Jurnal EP Unud, 8(8), 1789-1823.

Syahrul, S. R., \& Desmulyati. (2019). Perancangan Website Sistem Informasi Simpanpinjam Menggunakan Framework Codeiginter Pada Koperasi Bumi Sejahtera Jakarta. PERANCANGAN WEBSITE SISTEM INFORMASI SIMPAN PINJAM MENGGUNAKAN FRAMEWORK CODEIGINTER PADA KOPERASI BUMI ISSN : 2579-5201 (Printed) PERANCANGAN SEJAHTERA JAKARTA Syahrul, 3(1), 21-28. 